\title{
Kernos
}

Revue internationale et pluridisciplinaire de religion grecque antique

$10 \mid 1997$

Varia

\section{Did the Middle Helladic People Have Any Religion ?}

\section{Robin Hägg}

\section{OpenEdition}

\section{Journals}

Electronic version

URL: http://journals.openedition.org/kernos/641

DOI: 10.4000/kernos. 641

ISSN: 2034-7871

\section{Publisher}

Centre international d'étude de la religion grecque antique

\section{Printed version}

Date of publication: 1 January 1997

Number of pages: 13-18

ISSN: 0776-3824

\section{Electronic reference}

Robin Hägg, "Did the Middle Helladic People Have Any Religion ? », Kernos [Online], 10 | 1997, Online since 12 April 2011, connection on 20 April 2019. URL : http://journals.openedition.org/kernos/641 ; DOI : 10.4000/kernos.641 
Kemos, 10 (1997), p. 13-18.

\title{
Did the Middle Helladic People
}

\author{
Have Any Religion?
}

To the memory of Jobn Caskey

The title of this paper is perhaps unnecessarily provocative considering the person to whose memory it was originally written and read ${ }^{1}$. Professor J.L. Caskey would certainly not have hesitated to give an affirmative answer to the question, the more so since he had himself excavated some of the artefacts I consider among the few objects with a certain cultic function from Middle Helladic times. I trust there are today very few people who would agree with the extreme view that the population on the Greek mainland was practically without a religion during the Middle Bronze Age and then happily adopted the Minoan religion wholesale at the beginning of the Late Bronze Age ${ }^{2}$. I think this view originated in the school of Arthur Evans which overestimated the Minoan influence upon the mainland, but it could - until relatively recently- be supported by the observation that there existed no archaeological evidence whatsoever of sanctuaries or cult implements from the Middle Helladic mainland. Even if such archaeological finds were still unavailable, we should indeed be very reluctant to accept the idea that any human population would have been completely without religious observances of some kind. We should rather be prepared to admit the possibility that their religious activities could have been of a nature that would not have left any traces in the archaeological record $^{3}$. However, there are now some traces that prove -at least to my satisfaction - that the Middle Helladic population of mainland Greece did practice some kind of religion, and this evidence is what I am going to present briefly in this paper.

1 This is a revised version of a paper given at a lecture evening organised by the Nicholas P. Goulandris Foundation - Museum of Cycladic and Ancient Greek Art, Athens, on 18 November 1991, to commemorate the tenth anniversary of the death of Professor J.L. Caskey.

2 See, for example, N. PLATON, in discussion, in R. HÄGG, N. MARINATOS (eds.), Sanctuaries and Cults in the Aegean Bronze Age. Proceedings of the First International Symposium at the Swedish Institute in Atbens, Stockholm, 1981 (Skrifter utgitna av Svenska institutet $i$ Athen, Series in $\left.-4^{\circ}, 28\right), \mathrm{p}$. 210.

3 This solution should also be considered for the Greek Dark Ages, a period which has yielded surprisingly little evidence of religious installations of any kind. See now Ch. SOURVINOU-INWOOD, Early sanctuaries, the eigbtb century and ritual space, in N. MARINATOS, R. HÄGG (eds.), Greek Sanctuaries. New Approaches, London \& New York, 1993, p. 1-17. 
To begin with the objects I hinted at in my introduction as found by Caskey: a couple of double axes from Lerna ${ }^{4}$. Double axes must not in themselves necessarily be interpreted as cult implements or cult symbols, since there are many double axes in the archaeological record that must have been working tools of everyday use ${ }^{5}$. These axes from Lerna are, however, of terracotta and thus useless for practical purposes. One (inv.no. L6.325) was found in a grave (BE-19), the other (L6.23) in a street of Lerna V, Phase D. Of the second one (Fig. 1), only one half is preserved to a length of $0.053 \mathrm{~m}$. It is decorated with an incised pattern of double lines along the edges and double diagonal lines forming an X. A similar decoration is engraved on a bronze double axe from Grave Circle $A$ at Mycenae ${ }^{6}$. The other axe is complete, but undecorated; its total length is $0.1128 \mathrm{~m}$. The axes from Lerna have been designated as "votive" 7 , but I think they may equally well be called "symbolic". I shall come back to their interpretation below.

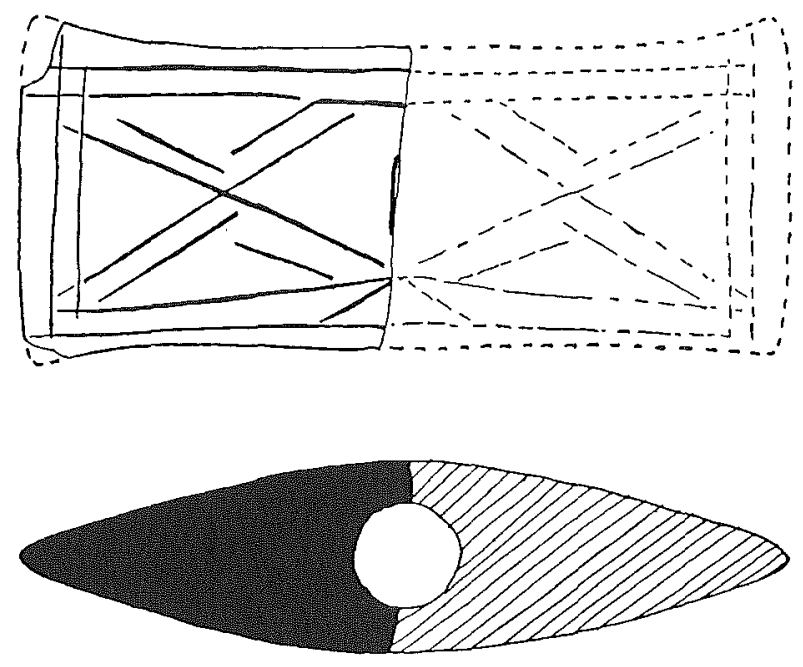

Fig, 1: Lerna. Middle Helladic double axe of terracotta. After CASKEY, art. cit. (n. 4), fig. 2.

4 J.L. CASKEY, in Hesperia, 26 (1957), p. 146 with fig. 2; E.C. BANKS, The Early and Middle Helladic Small Objects from Lema, Ph.D. Diss., Univ. of Cincinnati, 1967, p. 656-658 with pl. 21 (Nos. 1743-1744).

5 M.P. NILSSON, The Minoan-Mycenaean Religion and its Survival in Greek Religion, Lund, $1950^{2}$, p. 194-235; H.-G. BUCHHOLZ, Zur Herkunft der kretiscben Doppelaxt, München, 1959; C. MAVRIYANNAKI, La double bache dans le monde bellénique à l'âge du bronze, in RA (1983), p. 195-228.

6 G. KARO, Die Schacbtgräber von Mykenai, München, 1930-1933, p. 93, fig. 23.

7 BANKS, op.cil. (n. 4), p. 656. 


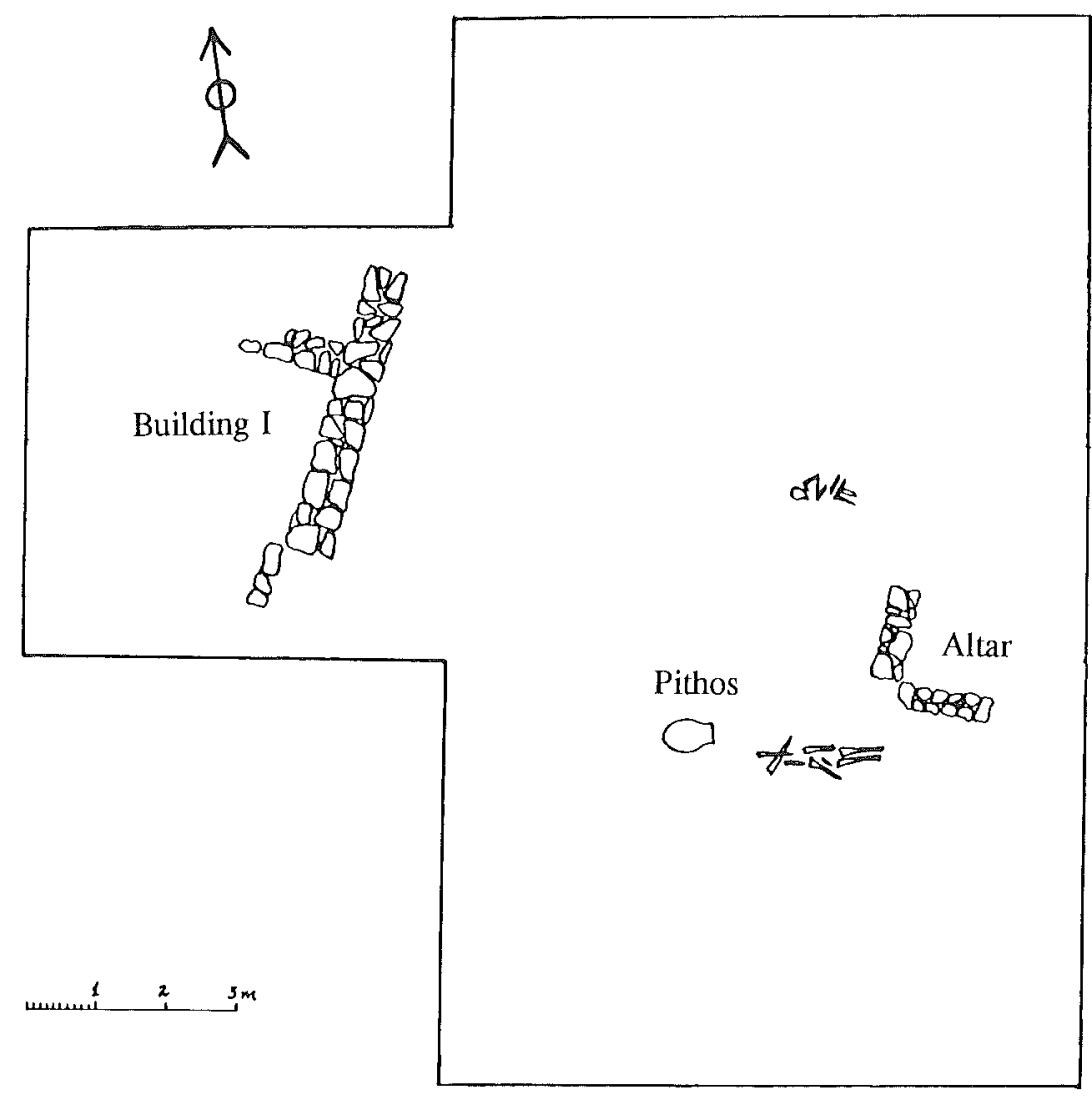

Fig. 2: Nisakouli. Plan of Middle Helladic cult place. Modified after CHOREMiS, art. cit. (n. 8), plan 1.

There are also two cult places that seem to have been in use in Middle Helladic times. One is an altar area on the small island of Nisakouli outside Methoni in Messenia, excavated by A. Choremis in 1968 and known only through a brief preliminary report ${ }^{8}$. Its main feature was a hearth or rather low altar (Fig. 2) consisting of a big heap of stones, among which were found quantities of burned animal bones, pot sherds and also of larger pieces of pots. Among the bones were pieces of deer horn and some tusks. The stone heap rested on black earth, hard-burned through fire? ${ }^{9}$. The pottery, dated by the excavator to the end of the Middle Helladic period, included sherds of Black and Grey Minyan and Mattpainted ware; also a few fragments of so-called Adriatic

8 A.C. CHOREMIS, M.E. altar on Nissakouli-Metboni (in Greek with Engl. summary), in $A A A, 2$ (1969), p. 10-14. Mentioned also BCH, 94 (1970), p. 996; F. SCHACHERMEYR, Die ägäiscbe Frïbzeit, 1: Die vormykeniscben Perioden des griechiscben Festlandes und der Kykladen, Vienna, 1976 (Mykeniscbe Studien, 3), p. 264. For the location of Nisakouli, see SCHACHERMEYR, op. cit., map at the end of the volume, no. 45 .

9 CHOREMIS, art. cit. (n. 8), p. 11, fig. 2. 
ware were found ${ }^{10}$. At least one of the fragmentary pots was of a special shape, a composite vessel consisting of two cups, certainly to be classified as a ritual vessel $^{11}$. The hearth or altar was located inside two stretches of dry-stone wall, each about $1.30 \mathrm{~m}$ long, meeting at right angles (Fig. 2); each wall had a finished end and there were no traces of any continuation ${ }^{12}$. According to the excavator, this wall would have protected the altar from the prevailing strong south and west winds. To judge from the information available so far, the cultic character of this find complex is rather obvious. However, a burial pithos and an earth-cut grave were found in the immediate vicinity ${ }^{13}$. If these were more or less contemporary with the altar construction, which is not certain ${ }^{14}$, the ceremonies performed here may have been related to funerary practices rather than to divine cult. There does not seem to be any remains of the Mycenaean period at this spot.

The second cult place to be discussed is potentially more important, since the cult continued here through the entire Mycenaean period. It is the Bronze Age shrine underneath the later sanctuary of Apollo Maleatas on the Kynortion Hill above the Asklepieion of Epidauros, explored during a long series of successive excavations by I. Papadimitriou and V. Lambrinoudakis ${ }^{15}$. Here, layers of ash, mixed with sherds and animal bones, were found on a terrace supported by a wall of Mycenaean date ${ }^{16}$. Bones of goats and bulls give evidence of animal sacrifice, most probably followed by communal feasting. The most common pot shapes are those used for feasting, i.e. cups and bowls. The earliest pottery found is Middle Helladic ${ }^{17}$ and may indicate that the cult could have begun in a late phase of the Middle Helladic period and continued without a break into the Late Helladic period (i.e., over our artificial, chronological boundary). It is, however, possible that the early pottery might have come from

10 CHOREMis, art. cil. (n. 8), p. 12, figs. 3-4. On the chronology of the "Adriatic Ware", see now R. TREUIL, Le néolitbique et le Bronze Ancien égéens, Athènes \& Paris, 1983 (BEFAR, 248), p. 44-45.

11 CHOREMis, art. cit. (n. 8), p. 12-13, fig. 5. A similar, but better preserved, specimen (consisting, however, of two jugs, not cups) was found in the Middle Helladic cist grave 1971-2 at Asine, S. DIETZ, Asine II, Fasc. 2: The Middle Helladic Cemetery, the Middle Helladic and Early Mycenaean Deposits, Stockholm, 1980 (Skrifter utgivna av Svenska institutet i Atben, Series in-4ㅁ,24:2), p. 33-34, fig. 26.

12 CHOREMis, art. cit. (n. 8), 11-13, figs. 2 and 6, plan 1 (here = Fig. 2).

13 CHOREMIS, art. cit. (n. 8), p. 14, plan 1 (= Fig. 2).

14 There were also the walls of a small building at a distance of some $10 \mathrm{~m}$ west-north-west of the altar; the pottery found in or around the building points to the same period as that of the altar; CHOREMIS, art. cit. (n. 8), p. 14, cf. fig. 1 (plan). It is, however, not quite clear whether the same date should be given also to the two burials.

15 I. PAPADIMITRIOU, PAE (1948), p. 90-111; (1949), p. 91-99; (1950), 194-202; (1951), p. 204-212; V. LAMBININOUDAKIS, PAE (1974), p. 96; (1975), p. 167-171; (1976), p. 202-207; (1977), p. 187-191; (1978), p. 111-121; (1979), p. 127-129; (1980), p. 103; (1981), p. 157-181; (1983), p. 151-159; (1984), p. 229-232; (1987), p. 52-65; (1988), p. 21-29; (1989), p. 43-56; (1990), p. 45-49.

16 V. LAMBRINUDAKIS, Remains of the Mycenaean Period in the Sanctuary of Apollon Maleatas, in Sanctuaries and Cults in the Aegean Bronze Age, op. cit. (n. 2), p. 59-65, esp. p. 59.

17 LAMBRINUDAKIS, art. cit. (n. 16), p. 63; ID., Staatskult und Gescbicbte der Stadt Epidauros, in Arcbaiognosia, 1 (1980), p. 43-45. 
the nearby prehistoric settlement; in that case it would not be the traces of an early cult ${ }^{18}$. On the other hand, the very high quality of this painted Middle Helladic pottery ${ }^{19}$ is not characteristic of a purely domestic context, but speaks strongly for a cultic use.

In the ash layers in the Kynortion shrine were found numerous bronze double axes of the well-known Minoan type ${ }^{20}$. Although they belong chronologically to the Late Helladic period, they should be seen as associated with the rite of animal sacrifice that I think was performed here from late Middle Helladic times onwards. Not that these double axes, mostly of very thin material, could have been used for the sacrifice, but they would rather have functioned as symbols, put up on display during the ritual ${ }^{21}$. Here we may have the explanation of the terracotta double axes from Lerna. They, too, are without a purely practical function, but they alluded, as it were, to the age-old connection between double axe and animal sacrifice, and especially bull sacrifice, a connection so clearly seen in Minoan Crete $^{22}$.

If the interpretation of the finds in the Maleatas sanctuary is correct, animal sacrifice and subsequent communal feasting were important elements of not only Mycenaean, but already Middle Helladic, ritual. This is hardly surprising, since both are basic elements in many religious cults and naturally often occur together. There is, however, no reason to suppose that the animal sacrifice was of the type characteristic of Greek cult of the historical period, i.e. the burnt sacrifice, whereby certain parts of the animal were burnt on the altar. This type does not seem to appear until after the Bronze Age $^{23}$. The traces of fire and burning in Bronze Age sanctuaries is rather to be explained, as Bergquist has suggested $^{24}$, as connected with the preparation of the sacred meal following the sacrifice, i.e. the ritual slaughtering of the animal, and with the subsequent disposal of the refuse from the meal.

It is likely that we can postulate yet another basic type of cult practice already for the Middle Helladic period: the libation, the pouring of a liquid as an

18 LAMBRINOUDAKIS, in PAE (1988), p. 21-22; cf. Ergon (1988), p. 13; BCH, 113 (1989), p. 604; O. DICKINSON, The Aegean Bronze Age, Cambridge, 1994, p. 283.

19 LAMBRINOUDAKIS, art. cit. (n. 17), 43.

20 LAMBRINUDAKIS, art. cit. (n. 16), p. 62 with figs. 10 and 12.

21 R. HÄGG, Mycenaean Religion: the Helladic and the Minoan Components, in A. MORPURGO DAVIES, Y. DUHOUX (eds.), Linear B: a 1984 Survey, Louvain-la-Neuve, 1985, p. 203-225, esp. p. 207 and 210.

22 N. MARINATOS, Minoan Sacrificial Ritual. Cult Practice and Symbolism, Stockholm, 1986 (Skrifter utgivna av Svenska institutet $i$ Atben, Series in- $8^{\circ}, 9$ ).

23 B. BERGQUIST, The Archaeology of Sacrifice: Minoan-Mycenaean versus Greek, in R. HÄGG, N. MARINATOS, G.C. NORDQUIST (eds.), Early Greek Cult Practice, Stockholm, 1988 (Skrifter utgivna av Svenska institutet $i$ Athen, Series in- $\left.4^{\circ}, 38\right)$, p. 21-34; EAD., Bronze Age Sacrificial Koine in the Eastern Mediterranean?, in J. QUAEGEBEUR (ed.) Ritual and Sacrifice in the Ancient Near East, Leuven, 1993, p. $11-43$.

24 BERGQUIST, art. cit. (n. 23), 1988. 
offering to a divine or supernatural recipient ${ }^{25}$. This also occurs as standard practice in various ancient cultures, such as the Minoan, the Mycenaean and the Hittite. Both Minoans and Mycenaeans had a number of specialized vase shapes for the purpose of pouring libations, such as jugs and rhyta, and it is clear that the Mycenaean Greeks took over such shapes from the Minoans ${ }^{26}$. As I have argued elsewhere ${ }^{27}$, it is likely that the custom of libation existed on the Greek mainland already before the introduction of the Minoan types of rhyta in the Early Mycenaean period, that is that the Mainlanders adopted the foreign implements to embellish, as it were, an already existing cult practice. How did they perform libations before this time? We cannot distinguish any specific shape for this purpose, but I suggest that libations were anyway made with the help of ordinary vessels, whether of open or closed shape. This must have been common in Classical Greece, where every meal was preceded by a libation to the Agathos Daimon from a drinking $\operatorname{cup}^{28}$; I think similarly the Mycenaeans performed most of their libations by means of ordinary kylikes, not rhyta ${ }^{29}$. If this is so, it is part of the explanation why we have found practically no material traces of Middle Helladic cult: there was no specific cult equipment, whose form would reveal its function ${ }^{30}$.

In conclusion, while the notion of a people without a religion was a priori highly dubious, I hope to have shown that there is now also some material evidence of the existence of cult practices in the Middle Helladic period and thus indirectly of an independent religious life of the Mainland population before the onset of the Cretan influence in the time of the Minoan thalassocracy.

Classical Archaeology and Ancient History

Robin $\mathrm{HÄGG}$

Göteborg University

S-41298 GÖTEBORG

25 W. BURKERT, Greek Religion, Oxford, 1985, p. 71.

26 R. HÄGG, The role of libations in Mycenaean ceremony and cult, in R. HÄGG and G.C. NORDQUIST (eds.), Celebrations of deatb and divinity in the Bronze Age Argolid, Stockholm, 1990 (Skrifter utgivna av Svenska institutet $i$ Atben, Series in-4 ${ }^{\circ}, 40$ ), p. 177-184, with refs.

$27 \mathrm{HÄGG}$, art. cit. (n. 26), p. 184.

28 H.J. ROSE, in Oxford Classical Dictionary, Oxford, $1970^{2}$, p. 1140 s.v. Worship, Housebold.

29 HÄGG, art. cit. (n. 26), p. 183.

30 For a conspectus of Middle Helladic (Mattpainted) pot shapes, of which a certain number could well be thought of as appropriate for the performing of libations, see R.J. BUCK, Middle Helladic Mattpainted Pottery, in Hesperia, 33 (1964), p. 231-313, pls. 39-41. 